\begin{tabular}{l|l|l} 
Jurnal Eksplorasi Akuntansi & $\begin{array}{l}\text { ISSN : 2656-3649 (Online) } \\
\text { hol 2, No 1, Seri B, Februari 2019, Hal 2129-2141 }\end{array}$
\end{tabular}

\title{
PENGARUH VOLATILITAS ARUS KAS, VOLATILITAS PENJUALAN, DAN PERBEDAAN LABA AKUNTANSI DENGAN LABA FISKAL TERHADAP PERSISTENSI LABA
}

(Studi Empiris pada Perusahaan Manufaktur yang Terdaftar di BEI Tahun 2014-2018)

\author{
Doli Andi ${ }^{1}$, Mia Angelina Setiawan ${ }^{2}$ \\ ${ }^{1}$ Alumni Jurusan Akuntansi Fakultas Ekonomi Universitas Negeri Padang \\ ${ }^{2}$ Jurusan Akuntansi Fakultas Ekonomi Universitas Negeri Padang \\ *Korespondensi: doliandixiak2@gmail.com
}

\begin{abstract}
Abstrack: This study aimed to examine the effect of the volatility of cash flows, sales volatility and differences in accounting income with taxable income of the persistence of earnings. This research is classified research causative. The population in this research is manufacturing companies listed in Indonesia Stock Exchange in 2014-2018. By using purposive sampling method, there are 42 companies as samples. The data used is secondary data obtained from www.idx.co.id. The analytical method used is a panel regression analysis. The results of this study indicate that the volatility of cash flow and significant negative effect on the persistence of earnings, while variable sales volatility and differences in accounting income to taxable income has no effect on earnings persistence.
\end{abstract}

Keywords : the persistence of earnings, cash flow volatility, volatility of sales and differences in accounting profit to taxable profit

How to cite (APA $6^{\text {th }}$ style):

Andi, D \& Setiawan, M. (2020). Pengaruh Volatilitas Arus Kas, Volatilitas Penjualan, dan Perbedaan Laba Akuntansi dengan Laba Fiskal Terhadap Persistensi Laba (Studi Empiriris pada Perusahaan Manufaktur yang Terdaftar di BEI Tahun 2014-2018). Jurnal Eksplorasi Akuntansi, 2(1), Seri B, 2129-2141.

\section{PENDAHULUAN}

Suatu pertanggungjawaban perusahaan dalam periode tertentu kepada berbagai pihakpihak yang berkaitan dengan perusahaan disebut dengan pelaporan keuangan. Menurut PSAK No.1 Tahun 2015, suatu penyampaian terstruktur dari kondisi entitas dalam keuangannya adalah laporan keuangan. Laporan keuangan bertujuan untuk memberikan informasi mengenai posisi keuangan, kinerja keuangan, arus kas entitas, yang bagi sebagian besar kalangan pengguna laporan dalam pemutusan sebuah keputusan ekonomi sangatlah bermanfaat. Laporan keuangan terdiri dari 5 laporan, yang pertama laporan posisi keuangan yang menyajikan posisi keuangan suatu entitas, yang kedua laporan laba rugi komprehensif yang memperlihatkan laba rugi suatu entitas, yang ketiga laporan perubahan ekuitas, yang keempat laporan arus kas, dan yang kelima catatan atas 
laporan keuangan. Karakteristik kualitatif laporan keuangan yaitu relevan, andal, dapat dipahami, dan dapat dibandingkan.

Tujuan utama perusahaan didirikan adalah menghasilkan laba, karena salah satu aspek penting bagi perusahaan adalah laba. Supaya perusahaan selalu sehat, setiap perusahaan harus menghasilkan laba yang tinggi. Tapi dengan laba yang tinggi saja tidaklah cukup. Perusahaan juga harus menghasilkan laba yang memperlihatkan kondisi pereusahaan yang sebenarnya dan dapat menjadi panduan agar bisa memperkirakan laba pada periode selanjutnya. Dengan kata lain perusahaan sangat mengharapkan laba yang persisten yang mana laba yang persisten sangat penting bagi perusahaannya (Suwandika dan Astika, 2013).

Laba yang dapat memberikan bayangan atas kelanjutan laba dimasa yang akan datang adalah salah satu ciri dari laba yang berkualitas (Djamaludin, 2008). Maksud dari kelanjutan laba tersebut adalah kemampuan yang dimiliki laba untuk bisa bertahan dimasa akan datang dalam keadaan sehat. Oleh karena itu para investor tidak hanya harus memperhatikan laba yang tinggi saja, namun juga harus memperhatikan laba yang persisten, yang artinya berkelanjutan untuk masa yang akan datang (Fanani, 2010). Dengan melihat persistensi laba, stakeholders dapat mengevaluasi kejadian-kejadian ditahun-tahun sebelumnya, sekarang dan masa akan datang. Laba dengan tingkat persistensi yang tinggi sangat berguna untuk memprediksi laba dimasa depan.

Penelitian ini mengacu kepada penelitian yang dilakukan Fanani pada tahun 2010. Perbedaan penelitian ini dengan penelitian Fanani yaitu peneliti menambahkan satu variabel independen yaitu perbedaan laba akuntansi dengan laba fiskal dan mengurangi variabel independen yaitu besaran akrual, tingkat hutang dan siklus operasi dan sampel yang saya ambil dari tahun 2014-2018. Hasil dari penelitian Fanani (2010) menunjukkan volatilitas arus kas dan volatilitas penjualan berpengaruh signifikan terhadap persistensi laba.

Motivasi peneliti melakukan penelitian ini adalah peneliti ingin mengkaji mengenai laba terutama tingkat persistensinya, karena laba adalah hal yang menjadi perhatian utama stakeholders untuk mengambil keputusan ekonomi. Penelitian ini menguji dan menganalisis pengaruh volatilitas arus kas, volatilitas penjualan dan perbedaan laba akuntansi dengan laba fiskal terhadap persistensi laba. Penelitian sebelumnya telah banyak yang meneliti terkait faktor-faktor yang mempengaruhi persistensi laba. Faktor-faktor yang diteliti seperti besaran akrual, book tax differences, keandalan akrual, arus kas operasi, arus kas akrual, ukuran perusahaan, volatilitas arus kas, kepemilikan manajerial, kepemilikan mayoritas, volatilitas penjualan, dan good corporate governance. Ditemukan hasil yang tidak sejalan dan tidak konsisten yang membuat peneliti tertarik untuk melakukan penelitian terkait dengan persistensi laba tersebut.

Sampel dalam penelitian ini adalah perusahaan manufaktur yang terdaftar di Bursa Efek Indonesia (BEI) tahun 2014-2018. Alasan peneliti memilih perusahaan manufaktur sebagai sampel adalah karena manufaktur memiliki komponen dan pelaporan keuangan yang lengkap sehingga memungkinkan peneliti mendapatkan data yang diperlukan dengan mudah. Untuk periode pengamatan peneliti mengambil periode terbaru agar lebih menggambarkan keadaan sebenarnya dari perusahaan manufaktur saat ini. Penelitian memiliki tujuan agar mendapatkan bukti empiris terkait pengaruh volatilitas arus kas, volatilitas penjualan dan perbedaan laba akuntansi dengan laba fiskal terhadap persistensi laba pada perusahaan manufaktur yang terdaftra di Bursa Efek Indonesia pada tahun 2014-2018. 


\section{REVIU LITERATUR DAN HIPOTESIS Persistensi Laba}

Fanani (2010) mengatakan revisi yang diharapkan di masa akan datang berupa laba akuntansi yang disebabkan oleh pergerakan perubahan laba tahun berjalan disebut dengan persistensi laba. Bagi stakeholders pelaporan laba sangat bermanfaat dalam pengambilan keputusan investor dan untuk menentukan laba dimasa yang akan dating kreditor dapat melihat laba saat ini. Hasil prediksi yang lebih tepat akan diperoleh jika laba berkualitas, karena untuk menghindari kesalahan dalam memprediksi. Salah satu ukuran yang dapat memprediksi laba dimasa depan adalah persistensi laba. Jika suatu perusahaan ingin perusahaannya dikatakan memiliki kinerja yang baik maka perusahaan tersebut harus mampu menghasilkan laba yang persisten. Pada saat aliran kas dan laba akrual berpengaruh terhadap laba tahun depan maka saat itulah laba dikatakan persisten dan perusahaan dapat mempertahankan jumlah laba yang diperoleh saat ini sampai masa yang akan datang.

\section{Volatilitas Arus Kas}

Pergerakan dana masuk dan dana keluar pada suatu badan usaha yang sedang berjalan disebut dengan arus kas. Yang mana hal itu berkaitan dengan waktu transaksi tunai sesuai penggunaan dana tunai yang digunakan untuk asset. Suatu proses dan cara suatu perusahaan dalam membangkitkan dana tunai dan menggunakan dana tunainya tersebut disebut dengan arus kas (Fanani, 2010). Dalam PSAK No.2 dikatakan bahwa laporan arus kas harus dilaporkan secara rutin selama periode tertentu dan dibagi dengan pengklasifikasian sebagai aktivitas operasi, investasi, dan pendanaan. Pengklasifikasian tersebut berguna untuk memberikan informasi yang memungkinkan para pengguna laporan keuangan untuk menilai dan membedakan pengaruh aktivitas tersebut sesuai dengan aktivitas masing-masing terhadap posisi keuangan perusahaan serta terhadap jumlah kas dan setara kas. Dan untuk menganalisa hubungan dari ketiga aktivitas tersebut juga dapat digunakan informasi tersebut.

\section{Volatilitas Penjualan}

Dalam menghasilkan laba dari siklus operasi perusahaan penjualan adalah bagian terpenting dari siklus operasi tersebut. Kemampuan laba dalam memprediksi aliran kas di masa yang akan datang ditunjukkan oleh volatilitas penjualan yang rendah. Suatu ukuran yang menunjukkan tingkat fluktuasi atau pergerakan penjualan selama satu periode disebut dengan volatilitas penjualan (Nina, et. al, 2014). Suatu volatilitas lingkungan operasi dan penyimpangan lebih besar aproksimasi dan estimasi, dan berkorespondensi dengan kesalahan estimasi yang lebih besar dan kualitas akrual yang rendah diindikasikan oleh volatilitas penjualan.

\section{Perbedaan Laba Akuntansi dengan Laba Fiskal}

Penyesuaian-penyesuaian pada laporan keuangan komersial yang diatur oleh peraturan perpajakan di Indonesia yang menyebabkan terjadinya perbedaan laporan keuangan disebut dengan rekonsiliasi fiskal. Perbedaan antara laba akuntansi dengan laba fiskal terjadi karena rekonsiliasi fiskal yang dilakukan setiap akhir periode pembukuan akuntansi. Perbedaan tersebut ditimbulkan oleh adanya perbedaan ketentuan dalam pengakuan dan pengukuran antara standar akuntansi keuangan dan peraturan pajak (Martini dan Persada, 2009). Perbedaan itulah yang menimbulkan istilah book-tax differences dalam analisis perpajakan (Suwandika dan Astika, 2013). Book-tax Differences merupakan perbedaan jumlah laba yang dihitung berdasarkan akuntansi dengan laba yang dihitung sesuai dengan peraturan perpajakan (Hanlon, 2005). Sedangkan menurut ketentuan 
perundang-undangan perpajakan pada dasarnya antara akuntansi keuangan dan akuntansi pajak memiliki kesamaan tujuan, yaitu untuk menetapkan hasil operasi bisnis dengan pengukuran dan rekognisi penghasilan dan biaya.

\section{Pengembangan Hipotesis \\ Volatilitas Arus kas dan Persistensi Laba}

Indikator keuangan yang baik adalah arus kas, indikator arus kas ini dikatakan lebih baik dari pada laba karena laba memiliki komponen transitoris. Komponen transitoris mungkin muncul dikarenakan adanya perjanjian kompensasi atau perjanjian hutang yang merupakan salah satu alasannya. Sehingga manajer terpaksa untuk memanipulasi laba karena perjanjian hutang didasarkan pada laba akuntansi yang dilaporkan. Komponen transitoris dalam laba tersebutlah yang mengakibatkan laba memiliki persistensi yang rendah (Dechow dan Dichev, 2002). Volatilitas arus kas dapat menunjukan ketidakpastian dalam lingkungan operasi yang artinya semakin tinggi volatilitas arus kas maka semakin tinggi ketidakpastian lingkungan operasi sehingga dapat dikatakan volatilitas arus kas memberikan pengaruh terhadap persistensi laba. Untuk itu arus kas yang stabil dapat digunakan untuk mengukur persistensi laba, dimana arus kas yang digunakan adalah arus kas operasi yang memiliki volatilitas yang rendah. Sangat sulit untuk memprediksi arus kas dimasa depan jika jika arus kas sangat tinggi atau tidak stabil(Dechow dan Dichev, 2002).

Fanani (2010) membuktikan bahwa persistensi laba dipengaruhi oleh volatilitas arus kas secara negatif dan signifikan. Hasil ini sesuai dengan Dechow dan Dichev (2002) yang menyatakan bahwa arus kas berpengaruh negative dan signifikan terhadap persistensi laba. Hasil penelitian tersebut membuktikan bahwa persistensi laba yang rendah disebabkan oleh volatilitas arus kas yang tinggi. Namun pada penelitian Asma (2013) membuktikan bahwa volatilitas arus kas berpengaruh positif dan signifikan terhadap persistensi laba.

H1: Volatilitas arus kas berpengaruh negatif dan signifikan terhadap persistensi laba.

\section{Volatilitas Penjualan dan Persistensi Laba}

Untuk memperoleh laba kita harus memiliki aktivitas operasi yang paling utama, aktivitas operasi paling utama tersebut adalah penjualan. Kinerja perusahaan dalam mempromosikan dan menjual produk berupa barang atau jasa dikatakan bagus jika tingkat penjualan suatu perusahaan itu tinggi. Tingkat penjualan yang stabil dan memiliki volatilitas yang rendah cenderung lebih disukai oleh banyak investor. Laba perusahaan akan dipengaruhi oleh volatilitas penjualan yang rendah yang mana kemampuan laba yang rendah dalam memprediksi aliran kas yang dihasilkan dari penjualan di masa yang akan datang sehingga laba yang dihasilkan lebih persisten dapat ditunjukkan oleh volatilitas penjualan yang rendah.

Suatu volatilitas lingkungan operasi dan penyimpangan yang lebih besar aproksimasi dan estimasi, dan berkorespondensi dengan kesalahan estimasi yang lebih besar dan kualitas akrual yang rendah di indikasikan oleh volatilitas penjualan (Dechow dan Dichev, 2002). Laba dapat memprediksi aliran kas dimasa yang akan datang, kemampuan tersebut dapat ditunjukkan oleh volatilitas yang rendah dari penjualan.

H2: Volatilitas Penjualan berpengaruh negatif dan signifikan terhadap persistensi laba.

\section{Perbedaan Laba akuntansi dengan Laba Fiskal dan Persistensi Laba}

Saat prinsipal tidak dapat mengawasi aktivitas dan tidak mempunyai cukup informasi tentang kinerja yang dilakukan oleh agen maka terjadilah konflik keagenan, yang menyebabkan 
terjadinya asimetris informasi. Dalam mengambil keputusan dan mengevaluasi kinerja agen prinsipal sering menggunakan informasi akuntansi yang berkaitan dengan laba (Irfan dan Kiswara, 2013).Menurut SFAC No. 2 mengenai karakteristik kualitatif informasi akuntansi menyatakan bahwa kualitas primer informasi akuntansi adalah relevansi dan reliabilitas. Persistensi laba sering digunakan sebagai alat ukur kualitas laba, dan persistensi laba bukan merupakan komponen dari definisi kualitas primer laba karena persistensi laba merupakan bagian dari karakteristik kualitatif relevansi yaitu prediktive value (Wijayanti, 2006).

Suwandika dan Astika (2013) mengatakan bahwa ciri-ciri dari laba yang persisten adalah laba yang tidak terlalu berfluktuasi sehingga persistensi laba disebut sebagai karakteristik nilai relevansi dan kualitas laba yang dilaporkan perusahaan adalah baik. Sehingga unsur relevansi yaitu persistensi laba. Sehingga persistensi laba yang dipengaruhi oleh beberapa informasi dalam booktax differences dapat membantu investor dalam menentukan kualitas laba dan nilai perusahaan. H3: Perbedaan laba akuntansi dengan laba fiskal berpengaruh negatif dan signifikan terhadap persistensi laba.

\section{Kerangka Konseptual}

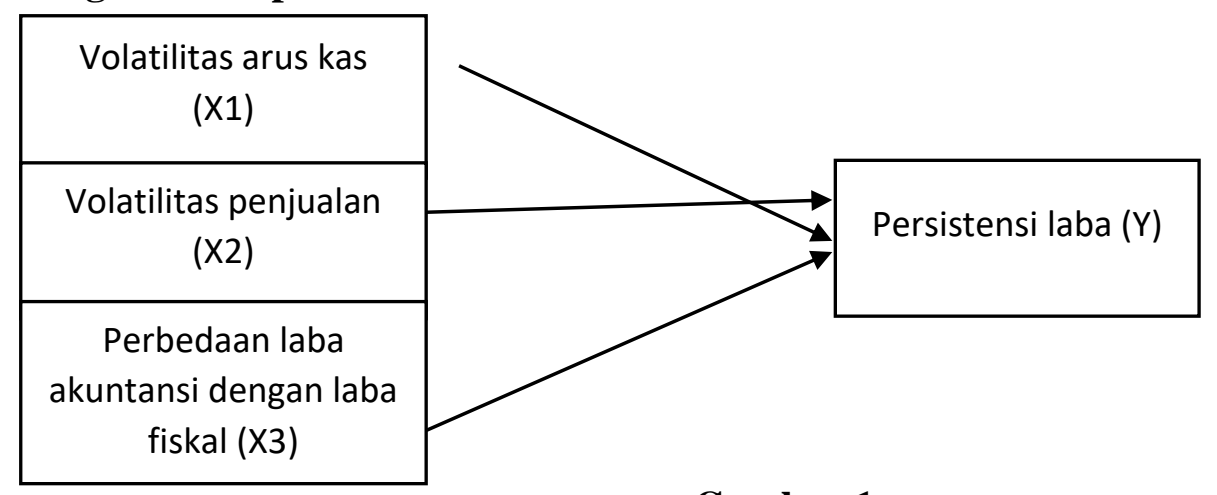

Gambar 1

Kerangka Konseptual

\section{METODE PENELITIAN}

Jenis penelitian ini adalah termasuk penelitian kausatif. Jenis data dalam penelitian ini adalah data sekunder. Data yang diperlukan dalam penelitian ini berupa laporan keuangan perusahaan manufaktur yang dipublikasikan tahun 2014-2018. Sumber data berasal dari situs resmi Bursa Efek Indonesia yaitu www.idx.co.id. Data ini berbentuk time series dan cross section sehingga data yang digunakan adalah data panel.

Populasi yang akan diamati dalam penelitian ini adalah seluruh perusahaan manufaktur yang terdaftar di Bursa Efek Indonesia (BEI) selama periode pengamatan yaitu tahun 2014-2018. Teknik pengambilan sampel yang digunakan dalam penelitian ini adalah purposive sampling. Kriteria yang digunakan dalam pemilihan sampel adalah perusahaan manufaktur yang terdaftar di Bursa Efek Indonesia, laporan keuaangan harus memiliki laba, memiliki data lengkap terkait variabel yang digunakan dalam penelitian, dan menyajikan mata uang rupiah $(\mathrm{Rp})$ yang konsisten selama periode pengamatan, yaitu tahun 2014-2018. Sehingga didapatkan sampel untuk penelitian sebanyak 42 perusahaan. 
Tabel 1

Kriteria Penentuan Sampel

\begin{tabular}{clc}
\hline No & \multicolumn{1}{c}{ Kriteria Sampel } & $\begin{array}{c}\text { Jumlah } \\
\text { Perusahaan }\end{array}$ \\
\hline 1 & $\begin{array}{l}\text { Perusahaan manufaktur yang terdaftar di Bursa Efek Indonesia } \\
\text { (BEI) periode tahun 2014-2018 }\end{array}$ & 159 \\
2 & $\begin{array}{l}\text { Peusahaan manufaktur yang tidak lengkap laporan keuangan di } \\
\text { BEI periode tahun 2014-2018 }\end{array}$ & $(52)$ \\
3 & $\begin{array}{l}\text { Perusahaan manufaktur yang tidak memiliki data lengkap } \\
\text { terkait variabel-variabel penelitian }\end{array}$ & $(0)$ \\
4 & $\begin{array}{l}\text { Perusahaan yang tidak menerbitkan laporan keuangannya } \\
\text { dengan mata uang rupiah (Rp) }\end{array}$ & $(27)$ \\
5 & $\begin{array}{l}\text { Perusahaan yang mengalami kerugian pada tahun 2014-2018 } \\
\text { Jumlah perusahaan sampel }\end{array}$ & $\mathbf{4 2}$ \\
& $\begin{array}{l}\text { Tahun penelitian } \\
\text { Total sampel selama tahun penelitian }\end{array}$ & $\mathbf{5 2}$ \\
\hline
\end{tabular}

(Sumber: IDX.co.id, data diolah)

\section{Variabel Penelitian \& Pengukurannya}

\section{Persistensi Laba}

Variabel dependen dalam penelitian ini adalah persistensi laba. Mengikuti penelitian fanani (2010). Persistensi laba akan diukur dengan persamaan berikut:

$$
\mathrm{ROA}_{t+1}=\alpha+\beta \mathrm{ROA}_{t}+€
$$

Dimana, $\mathrm{ROA}_{\mathrm{t}+1}$ adalah ROA satu tahun setelah periode sekarang. ROA $\mathrm{t}$ adalah ROA periode sekarang. $\alpha$ adalah nilai konstanta. $\beta$ adalah slope persistensi laba. $€$ adalah komponen eror.

\section{Volatilitas Arus Kas}

Variabel independen yang pertama dalam penelitian ini adalah volatilitas arus kas. Mengikuti penelitian Fanani (2010). Volatilitas arus kas akan diukur dengan persamaan berikut:

\section{$\sigma(C F O) t$ \\ Total Aktivajt}

Dimana, $\boldsymbol{\sigma}(\boldsymbol{C F O}) \boldsymbol{t}$ adalah rata-rata aliran kas operasi perusahaan selama tahun penelitian. Total aktiva ${ }_{j t}$ adalah total aktiva perusahaan $\mathrm{j}$ tahun $\mathrm{t}$.

\section{Volatilitas Penjualan}

Variabel independen yang kedua dalam penelitian ini adalah volatilitas penjualan. Mengikuti penelitian Fanani (2010). Volatilitas penjualan diukur dengan persamaan berikut:

\section{o(Penjualan selama 5 tahun $\left._{j t}\right)$ Total Aktivajt}

Dimana, $\boldsymbol{\sigma}\left(\text { Penjualan selama } 5 \text { tahun }_{j}\right)_{\mathrm{t}}$ adalah rata-rata penjualan selama lima tahun. Total aktivajt adalah total aktiva perusahaan pada tahun penelitian. 


\section{Perbeaan Laba Akuntansi dengan Laba Fiskal}

Variabel independen yang ketiga dalam penelitian ini adalah perbeaan laba akuntansi dengan laba fiskal. Mengikuti penelitian Wiryandari (2009). Perbedaan laba akuntansi dengan laba fiskal diukur dengan persamaan berikut:

\section{Beban Pajak Tangguhan jt Total Aktiva jt}

Dimana beban pajak tangguhan jt adalah beban pajak tangguhan pada tahun penelitian. Total aktiva $\mathrm{j}_{\mathrm{j}}$ adalah total aktiva pada tahun penelitian.

\section{HASIL DAN PEMBAHASAN}

\section{Statistik Deskriptif}

Sebelum variabel penelitian dianalisis dengan melakukan pengujian rumus statistik eviews 10, data dari masing-masing variabel penelitian dideskripsikan terlebih dahulu. Hal ini dimaksudkan agar dapat memberikan gambaran tentang masing-masing variabel yang diteliti. Tabel 2 Analisis Deskriptif akan menggambarkan statistik deskriptif dari 42 perusahaan manufaktur yang dijadikan sampel penelitian yang akan dianalisis lebih lanjut. Pada Tabel 2 Analisis Deskriptif, diketahui rata-rata persistensi laba adalah sebesar 9,49\%, volatilitas arus kas sebesar $9,92 \%$, volatilitas penjualan sebesar $114,93 \%$, perbedaan laba akuntansi dengan laba fiskal sebesar $-0,000837$.

Tabel 2

Statistik Deskriptif

\begin{tabular}{lccccc}
\hline & $\mathrm{Y}$ & $\mathrm{X} 1$ & $\mathrm{X} 2$ & $\mathrm{X} 3$ \\
\hline Mean & 0.094945 & 0.099206 & 1.149392 & -0.000837 \\
Median & 0.066050 & 0.071700 & 1.117250 & -0.000400 \\
Maximum & 1.380900 & 0.554500 & 3.319600 & 0.011700 \\
Minimum & 0.000300 & -0.023900 & 0.222500 & -0.027100 \\
Std. Dev. & 0.124081 & 0.092389 & 0.572217 & 0.004869 \\
Skewness & 5.998140 & 2.383596 & 1.012457 & -1.336200 \\
Kurtosis & 57.57276 & 10.31762 & 4.758900 & 8.330108 \\
& & & & \\
Jarque-Bera & 27318.34 & 667.3944 & 62.94757 & 311.0780 \\
Probability & 0.000000 & 0.000000 & 0.000000 & 0.000000 \\
& & & & \\
Sum & 19.93850 & 20.83330 & 241.3724 & -0.175700 \\
Sum Sq. Dev. & 3.217809 & 1.783979 & 68.43340 & 0.004954 \\
& & & & \\
Observations & 210 & 210 & 210 & 210 \\
(Sumber: Data Olahan Eviews10 tahun 2019)
\end{tabular}

\section{Analisis Model regresi}

Berdasarkan hasil Chow Test (Tabel 3) dan Hausman Test (Tabel 4) dengan menggunakan eviews 10: Hasil Estimasi Model Regresi Panel, digunakan dalam model ini adalah Fixed Effect Model (FEM) untuk penelitian ini. Serta, perlu dilakukan uji asumsi klasik terhadap penelitian tersebut (Hasil Uji Asumsi Klasik: Gambar 2, Tabel 5, Tabel 6, dan Tabel 7). 
Tabel 3

Hasil Chow Test

\begin{tabular}{llll}
\hline Effects Test & Statistic & d.f. & Prob. \\
\hline Cross-section F & 3.728422 & $(41,165)$ & 0.0000 \\
Cross-section Chi-square & 137.693268 & 41 & 0.0000 \\
\hline
\end{tabular}

(Sumber: Data Olahan Eviews10 tahun 2019)

Tabel 4

Hasil Hausman Test

\begin{tabular}{llll}
\hline Test Summary & $\begin{array}{l}\text { Chi-Sq. } \\
\text { Statistic }\end{array}$ & Chi-Sq. d.f. & Prob. \\
\hline Cross-section random & 79.733646 & 3 & 0.0000 \\
\hline
\end{tabular}

(Sumber: Data Olahan Eviews10 tahun 2019)

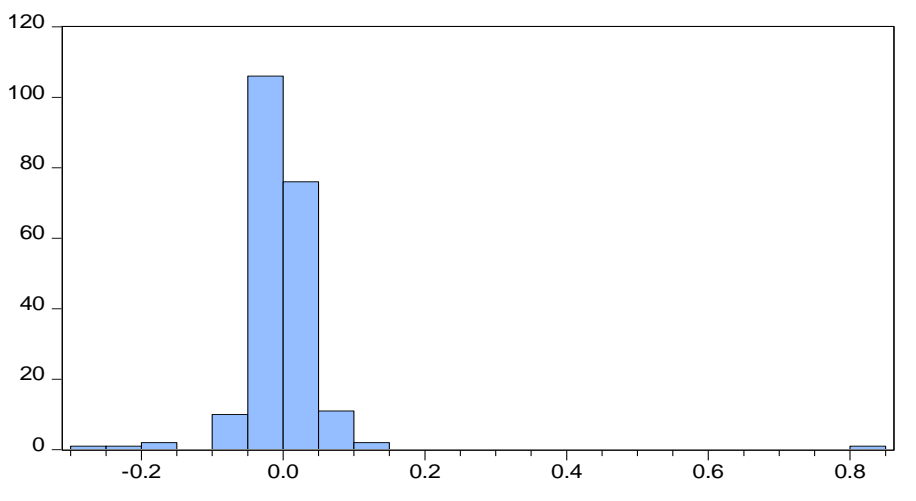

Gambar 2

\begin{tabular}{|lc|}
\hline Series: Standardized Residuals \\
Sample 2014 2018 \\
Observations 210 \\
Mean & $-1.32 e-19$ \\
Median & -0.001879 \\
Maximum & 0.840027 \\
Minimum & -0.270575 \\
Std. Dev. & 0.073082 \\
Skewness & 6.866552 \\
Kurtosis & 85.82330 \\
& \\
Jarque-Bera & 61672.61 \\
Probability & 0.000000 \\
\hline
\end{tabular}

Series: Standardized Residuals Sample 20142018

Observations 210

Mean $\quad-1.32 \mathrm{e}-19$

Minimum $\quad-0.270575$

Std. Dev. $\quad 0.073082$

Skewness $\quad 6.866552$

Probability $\quad 0.000000$

\section{Hasil Uji Normalitas Residual Model 1}

Tabel 5

Hasil Uji Heterokedastisitas

heterokedasticity Test : White

model penelitian Obs*R-squared Prob. Chi-Square

\begin{tabular}{lll}
\hline model regresi & 7.1028 & 0.0532
\end{tabular}

(Sumber: Data Olahan Eviews10 tahun 2019)

Tabel 6

Hasil Uji Multikolinearitas

\begin{tabular}{llll}
\hline & $\mathrm{X} 1$ & $\mathrm{X} 2$ & $\mathrm{X} 3$ \\
\hline $\mathrm{X} 1$ & 1 & 0.2727 & -0.0014 \\
$\mathrm{X} 2$ & 0.2727 & 1 & -0.1530 \\
$\mathrm{X} 3$ & -0.0014 & -0.1530 & 1 \\
\hline
\end{tabular}

(Sumber: Data Olahan Eviews10 tahun 2019) 
Tabel 7

Hasil Uji Auto Korelasi: Durbin Watson

\begin{tabular}{ll}
\hline $\begin{array}{l}\text { Uji Durbin Watson } \\
\text { model penelitian }\end{array}$ & Durbin-Watson Stat \\
\hline model regresi & 1.688133 \\
\hline
\end{tabular}

(Sumber: Data Olahan Eviews10 tahun 2019)

\section{Uji Model}

\section{Koefisien Determinasi (adjusted $\mathbf{R}^{2}$ )}

Berdasarkan hasil regresi pada Tabel 4.11 nilai adjusted $R^{2}$ yang diperoleh sebesar 56,06\%. Hal ini menyatakan bahwa 56,06\% variabel independen berpengaruh terhadap variabel dependen pada model ini untuk ketiga hipotesis dan ditentukan oleh variabel lain yang tidak dianalisis dalam model penelitian ini sebesar $43,94 \%$.

Tabel 8

Hasil Regresi Panel

\begin{tabular}{|c|c|c|c|}
\hline Variabel & & Prediksi & Hasil Regresi \\
\hline \multirow[t]{2}{*}{ Konstanta } & Coef & & $0.2471 * * *$ \\
\hline & t-stat & & 8.3340 \\
\hline \multirow[t]{2}{*}{$\mathrm{X} 1$} & Coef & - & -1.9178 \\
\hline & t-stat & & $-5.2095 * * *$ \\
\hline \multirow[t]{2}{*}{$\mathrm{X} 2$} & Coef & + & 0.0327 \\
\hline & t-stat & & 1.0735 \\
\hline \multirow[t]{2}{*}{$\mathrm{X} 3$} & Coef & - & -0.6166 \\
\hline & t-stat & & -0.4476 \\
\hline \multicolumn{3}{|l|}{ Adj R-Square } & 0.5606 \\
\hline \multicolumn{3}{|l|}{ F-Statistic } & $7.0601 * * *$ \\
\hline \multicolumn{4}{|l|}{ Keterangan } \\
\hline \multicolumn{4}{|c|}{ X1 : Volatilitas Arus Kas } \\
\hline \multicolumn{4}{|c|}{ X2 : Volatilitas Penjualan } \\
\hline \multicolumn{4}{|c|}{ X3 : Perbedaan Laba Akuntansi dengan Laba Fiskal } \\
\hline \multicolumn{4}{|c|}{$* * *, * *, *$ Signifikan pada $\alpha 1 \%, 5 \%$ dan } \\
\hline $10 \%$ & & & \\
\hline
\end{tabular}

\section{Uji F}

Berdasarkan Tabel 4.11 diketahui bahwa $F$-statisic signifikan pada $1 \%$, yaitu lebih kecil dari signifkansi yang telah ditentukan pada penelitian ini yaitu, 5\%. Dan dapat dikatakan bahwa model regresi panel diterima atau model regresi ini menunjukkan tingkatan yang baik (good overall model fit) sehingga model regresi dapat digunakan mengukur ketiga hipotesis pada penelitian ini yaitu pengaruh volatilitas arus kas, volatilitas penjualan, perbedaan laba akuntansi dengan laba fiskal terhadap persistensi laba. 


\section{Uji T}

Berdasarkan tabel 4.11, maka diketahui bahwa:

1. Pada variabel volatilitas arus kas diperoleh nilai thitung sebesar 5,2095 dan probabilitasnya 0,0000. Jika dibandingkan dengan $t_{\text {tabel }}$ sebesar 2,02439, maka $t_{\text {hitung }}>t_{\text {tabel }}$ dan sig $<0,05$. Hal ini menunjukkan bahwa H1 diterima, yang artinya bahwa volatilitas arus kas berpengaruh signifikan negatif terhadap persistensi laba pada perusahaan manufaktur yang terdaftar di Bursa Efek Indonesia tahun 2014-2018.

2. Pada variabel volatilitas penjualan diperoleh nilai $t_{\text {hitung }}$ sebesar 1,0375 dan probabilitasnya 0,2846. Jika dibandingkan dengan $t_{\text {tabel }}$ sebesar 2,02439, maka $t_{\text {hitung }}<t_{\text {tabel }}$ dan sig $>0,05$. Hal ini menunjukkan bahwa $\mathrm{H} 2$ ditolak, yang artinya bahwa volatilitas penjualan tidak berpengaruh signifikan terhadap persistensi laba pada perusahaan manufaktur yang terdaftar di Bursa Efek Indonesia tahun 2014-2018.

3. Pada variabel perbedaan laba akuntansi dengan laba fiskal diperoleh nilai thitung sebesar 0,4475 dan probabilitasnya 0,6551. Jika dibandingkan dengan $t_{\text {tabel }}$ sebesar 2,02439, maka $t_{\text {hitung }}<$ $\mathrm{t}_{\text {tabel }}$ dan sig $>0,05$. Hal ini menunjukkan bahwa $\mathrm{H} 3$ ditolak, yang artinya bahwa perbedaan laba akuntansi dengan laba fiskal tidak berpengaruh signifikan terhadap persistensi laba pada perusahaan manufaktur yang terdaftar di Bursa Efek Indonesia tahun 2014-2018.

\section{Pembahasan}

\section{Pengaruh Volatilitas Arus Kas terhadap Persistensi Laba}

Volatilitas arus kas berpengaruh negatif dan signifikan terhadap persistensi laba adalah hipotesis pertama pada penelitian ini. Variabel persistensi laba pada penelitian ini diukur dengan ROA pada tahun sekarang. Untuk mengukur variabel volatilitas arus kas, maka dapat diukur dengan rata-rata arus kas operasi selama lima tahun (Fanani 2010). Berdasarkan hasil penelitian pada perusahaan manufaktur yang terdaftar di Bursa Efek Indonesia pada tahun 2014 sampai tahun 2018, didapati bahwa hipotesis (H1) diterima, hal ini menunjukkan bahwa volatilitas arus kas berpengaruh negatif dan signifikan terhadap persistensi laba. Hal ini dapat dilihat dari hasil regresi panel pada tabel 4.11, yang menunjukkan nilai signifikan dari variabel volatilitas arus kas lebih kecil dari $\alpha 5 \%$, yaitu $0,0000<5 \%$ serta, nilai $t_{\text {hitung }}>t_{\text {tabel }}$ yaitu 5,2095 $>2,02439$.

Perusahaan manufaktur yang memiliki volatilitas arus kas yang tinggi akan memiliki persistensi laba yang rendah yang diindikasikan oleh hasil penelitian ini yaitu pengaruh yang negatif dan signifikan. Kas merupakan salah satu dari banyak aset yang paling liquid dan paling mudah berpindah tangan. Kas dibutuhkan perusahaan untuk menjalankan berbagai kegiatan usaha, seperti membeli bahan baku, membayar utang \& bunga, membayar tenaga kerja, dan lain-lain. Perusahaan yang memiliki jumlah kas yang tinggi dapat memenuhi kebutuhan operasionalnya dan dapat mengalokasikan sumber daya dengan baik sehingga dapar meningkatkan laba perusahaan yang mana menyebabkan rendahnya kepersistensian laba suatu perusahaan.

Hasil penelitian ini sejalan dengan penelitian Fanani (2010) dan penelitian Kusuma \& Sadjiarto (2014). Yang mana Fanani (2010) membuktikan bahwa semakin besar fluktuasi arus kas maka persistensi laba akan semakin rendah yang artinya semakin rendahnya persistensi laba ditunjukkan oleh tingginya arus kas. Dikarenakan arus kas dimasa yang akan datang sulit diprediksi oleh informasi arus kas saat ini maka menyebabkan volatilitas yang tinggi sehingga menunjukkan persistensi laba yang rendah. 


\section{Pengaruh Volatilitas Penjualan terhadap Persistensi Laba}

Volatilitas penjualan berpengaruh negatif dan signifikan terhadap persistensi laba merupakan hipotesis kedua dalam penelitian ini. Dalam penelitian ini variabel volatilitas penjualan diukur dengan data rata-rata penjualan selama lima tahun (Fanani 2010). Berdasarkan hasil penelitian pada perusahaan manufaktur yang terdaftar di Bursa Efek Indonesia pada tahun 2014 sampai tahun 2018, ditemukan bahwa hipotesis (H2) ditolak. Hal ini menyatakan bahwa variabel ini berpengaruh yang artinya bahwa volatilitas penjualan tidak berpengaruh signifikan terhadap persistensi laba. Hal ini dapat dilihat dari hasil regresi panel pada tabel 4.11, yang menunjukkan nilai signifikan dari variabel volatilitas penjualan lebih besar dari $\alpha 5 \%$, yaitu $0,2846>5 \%$ serta, nilai $t_{\text {hitung }}<\mathrm{t}_{\text {tabel }}$ yaitu $1,0375<2,02439$.

Penelitian ini bertentangan dengan penelitian Fanani (2010) dan Kusuma \& Sadjiarto (2014) yang membuktikan bahwa volatilitas penjualan berpengaruh signifikan terhadap persistensi laba. Menurut Fanani (2010) volatilitas yang tinggi dari penjualan dapat memprediksi laba. Disamping itu para investor harus memperhatikan informasi besar kecilnya penjualan dan dengan begitu maka bisa dinyatakan pola penjualan diikuti oleh persistensi laba.Dalam penelitian ini dapat disimpulkan tidak adanya pengaruh volatilitas penjualan terhadap persistensi laba yang artinga setiap terjadi kenaikan atau penurunan pada volatilitas penjualan maka tidak ada efek bagi persistensi laba.

\section{Pengaruh Perbedaan Laba Akuntansi dengan Laba Fiskal terhadap Persistensi Laba}

Perbedaan laba akuntansi dengan laba fiskal berpengaruh negatif dan signifikan terhadap persistensi laba merupakan hipotesis kedua dalam penelitian ini. Dalam penelitian ini variabel ini diukur dan di proksikan ke beban pajak tangguhan (manfaat pajak tangguhan) yang dibagi dengan total aset. Berdasarkan hasil penelitian pada perusahaan manufaktur yang terdaftar di Bursa Efek Indonesia pada tahun 2014 sampai tahun 2018, didapati bahwa hipotesis (H3) ditolak. Hal ini mengatakan bahwa tidak ada pengaruh pada variabel ini yang artinya bahwa perbedaan laba akuntansi dengan laba fiskal tidak berpengaruh signifikan terhadap persistensi laba. Yang dapat dilihat dari hasil regresi panel pada tabel 4.11, yang menunjukkan nilai signifikan dari variabel perbedaan laba akuntansi dengan laba fiskal lebih besar dari $\alpha$ 5\%, yaitu 0,6551 $>5 \%$ serta, nilai $t_{\text {hitung }}<t_{\text {tabel }}$ yaitu $0,4475<2,02439$.

Penelitian ini tidak sejalan dengan penelitian Asma (2013) dan Kusuma \& Sadjiarto (2014). Menurut Asma (2013) perbedaan laba akuntansi dengan laba fiskal berpengaruh negatif dan signifikan terhadap persistensi laba. Sedangkan menurut Kusuma \& Sadjiarto (2014) apabila tingkat book tax gap mengalami kenaikan sebesar 1, maka persistensi laba akan mengalami penurunan sebesar 2,242. Sebaliknya, apabila book tax gap mengalami penurunan sebesar 1, maka persistensi laba akan mengalami kenaikan sebesar 2,242.

\section{SIMPULAN, KETERBATASAN DAN SARAN Simpulan}

Kesimpulan dari penelitian ini adalah yang pertama, volatilitas arus kas berpengaruh signifikan terhadap persistensi laba pada perusahaan manufaktur yang terdaftar di Bursa Efek Indonesia yang ditunjukkan oleh hasil uji t variabel volatilitas arus kas, dimana nilai thitung sebesar 5,2095 dan probabilitasnya sebesar 0,0000. Jika dibandingkan dengan tabel sebesar 2,02439, maka thitung > tabel dan sig $<0,05$. Sehingga H1 diterima. Yang kedua, volatilitas penjualan tidak berpengaruh signifikan terhadap persistensi laba pada perusahaan manufaktur yang terdaftar di Bursa Efek Indonesia yang ditunjukkan oleh hasil uji t variabel volatilitas penjualan, dimana nilai thitung sebesar 
1,0375 dan probabilitasnya sebesar 0,2846. Jika dibandingkan dengan $t_{\text {tabel }}$ sebesar 2,02439, maka thitung $<\mathrm{t}_{\text {tabel }}$ dan sig $>0,05$. Sehingga $\mathrm{H} 2$ ditolak. Yang ketiga, perbedaan laba akuntansi dengan laba fiskal tidak berpengaruh signifikan terhadap persistensi laba pada perusahaan manufaktur yang terdaftar di Bursa Efek Indonesia. Hasil ini ditunjukkan dari hasil uji t variabel volatilitas penjualan, dimana nilai thitung sebesar 0,4475 dan probabilitasnya sebesar 0,6551 . Jika dibandingkan dengan $t_{\text {tabel }}$ sebesar 2,02439, maka thitung $<t_{\text {tabel }}$ dan sig $>0,05$. Sehingga H3 ditolak.

\section{Keterbatasan}

Keterbatasan-keterbatasan dalam penelitian ini:

1. Jumlah sampel dipilih dengan mensyaratkan riteria-kriteria tertentu (purposive sampling), dengan membatasi kriteria sampel hanya untuk perusahaan manufaktur yang terdaftar pada Bursa Efek Indonesia (BEI) yang mendapatkan laba selama periode pengamatan dan jumlah sampel yang memenuhi kriteria-kriteria relatif sedikit yaitu 42 perusahaan. Oleh karena itu hasil penelitian ini tidak dapat digeneralisasi untuk perusahaan diluar manufaktur.

2. Penelitian ini hanya memakai tiga variabel yaitu volatilitas arus kas, volatilitas penjualan dan perbedaan laba akuntansi dengan laba fiskal, dan ternyata hasil koefisien determinasi (R2) yang kecil yaitu 56,06\%. Maka dibutuhkan variabel lain yang lebih dapat menjelaskan persistensi laba dari hasil tersebut.

\section{Saran}

Berdasarkan pembahasan dan pengambilan kesimpulan yang telah dilakukan terhadap hasil penelitian, maka penulis mengajukan saran sebagai berikut:

1. Penelitian selanjutnya dapat menambahkan menggunakan sampel perusahaan yang rugi agar dapat memberikan hasil yang lebih real. Dan mengembangkan model penelitian ini pada sektor lain selain sektor manufaktur.

2. Peneliti menyarankan kepada peneliti selanjutnya untuk menambahkan variabel lain yang mempengaruhi persistensi laba misalnya seperti besaran akrual dan tingkat hutang dikarenakan hasil $\mathrm{R}^{2}$ yang relatif rendah tersebut. Dan bisa jadi variabel tersebut juga bisa mendapatkan hasil $\mathrm{R}^{2}$ yang tinggi dan berpengaruh terhadap persistensi laba.

\section{DAFTAR PUSTAKA}

Asma, T. N. (2013). Pengaruh Aliran Kas dan Perbedaan antara Laba Akuntansi dengan Laba Fiskal terhadap Persistensi Laba. Jurnal Akuntansi, 1(1) seri E.

Barus, A. C., \& Rica, V. (2014). Analisis faktor-faktor yang mempengaruhi opini audit going concern pada perusahaan manufaktur di Bursa Efek Indonesia. Jurnal Wira Ekonomi Mikroskil, 4(2), 71-80.

Bursa Efek Indonesia. Laporan keuangan dan tahunan.www.idx.co.id/id id/beranda/perusahaantercatat/laporankeuangandantahunan (diakses 25 Juli 2019).

Brigham, Eugene F. and Joel F Houston. (1999). Manajemen Keuangan. Jakarta : Erlangga.

Brigham, Eugene F. dan Joel F. Houston. (2011). Dasar-dasar manajemen keuangan, Edisi 11, Penerjemah Ali Akbar Yulianto. Jakarta: Salemba Empat.

Brolin, A.R., dan Rohman, A. (2014). Pengaruh book tax differences terhadap pertumbuhan laba. Diponegoro Journal of Accounting, 3 (02), 1-13.

Darmadji \& Fakhruddin. (2011). Pasar modal di Indonesia, edisi 3. Jakarta: Salemba Empat. 
Dechow, P. and Dichev. (2002). The Quality Of Accruals And Earnings: The Role Of Accrual Estimation Errors. The Accounting Review, 77 (Supplement): 33-59.

Fanani, Z. (2010). Analisis faktor-faktor penentu persistensi laba. Jumal Akuntansi Dan Keuangan Indonesia, 7(faktor-faktor penentu persistensi laba), 109-123.

Ikatan Akuntan Indonesia. 2011. Standar Akuntansi Keuangan Revisi 2011. Jakarta: Salemba Empat.

Irfan, F. H., dan E. K. (2013). Pengaruh perbedaan laba akuntansi dan laba fiscal terhadap persistensi laba dengan komponen akrual dan aliran kas sebagai variabel moderasi (studi empiris pada perusahaan manufaktur yang terdaftar di bursa efek indonesia 2008-2011). Diponegoro Journal of Accounting, 2 (2): 1-13.

Kaunang, J.M. (2013). Analisis laporan arus kas sebagai alat ukur menilai kinerja pada Pt. Pegadaian (persero) cabang manado timur. Jurnal EMBA, 1(3): 455-464.

Kusuma, B., \& Sadjiarto, R. A. (2014). Analisa pengaruh volatilitas arus kas, volatilitas penjualan, tingkat hutang, book tax gap, dan tata kelola perusahaan terhadap persistensi laba. Tax \& Accounting Review, 4(1).

Nina, B.H., \& Arfan, M. (2014). Pengaruh volatilitas arus kas, volatilitas penjualan, besaran akrual, dan financial leverage terhadap persistensi laba pada perusahaan manufaktur yang terdaftar di bursa efek indonesia. Jurnal Akuntansi, 3(2), 1-12.

PSAK-1-Penyajian-Laporan-Keuangan-Revisi-2013-01062015.

Scoott, William R. 2009. Financial Accounting Theory Fifth Edition. Toronto: Pearson Prentice Hall.

Sloan, RG. 1996. Do Stock Prices Fully Reflect Information In Accruals and Cash Flow about Future Earning?. The Accounting Review, 71 (3), 289-315.

Sugiyono. 2017. Metode Penelitian Kombinasi (Mixed Methods). Bandung Alfabeta.

Sugianto, Denang. 2018. Laba Indofood Turun 12.7\% Jadi Rp 1,9 Triliun. https://m.detik.com/finance/bursa-dan-valas/d-4142401/laba-indofood-turun- jadi-rp19- triliun

Sunarto. (2010). Peran persistensi laba terhadap hubungan antara keagresifan laba dan biaya ekuitas. Kajian Akuntansi, 2(1): 22-38

Suwandika, I. M. A, Astika, I. B. P. (2013). Pengaruh perbedaan laba akuntansi, laba fiskal, tingkat hutang pada persistensi lab. E-Jurnal Akuntansi Universitas Udayana.

Waluyo. (2012). Akuntansi pajak. Jakarta: Salemba Empat.

Wijayanti, H.T. 2006. Analisis Pengaruh Perbedaan Antara Laba Akuntansi dan Laba Fiskal Terhadap Persistensi Laba, Akrual dan Arus Kas. Simposium Nasional Akuntansi 9, Padang 